\section{SAAAA \\ JOURNAL}

\title{
Getting Closer to the Primordial Panji? Panji Stories Carved in Stone at Ancient Javanese Majapahit Temples - and their Impact as Cultural Heritage Today
}

Dr Lydia Kieven

Independent Lecturer and Researcher University Bonn, University Cologne, Germany lydia.kieven@gmail.com

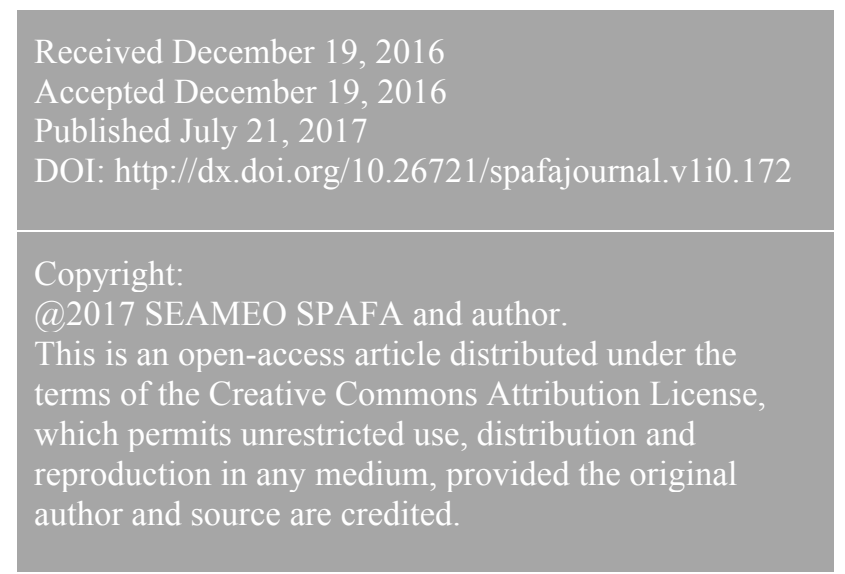

\begin{abstract}
In search of the roots of Panji, the paper raises the question to what extent the spread of the Panji theme in Southeast Asia is a manifestation of the political and cultural influence of Majapahit within the region. The East Javanese Majapahit kingdom (circa 1300 to $1500 \mathrm{CE}$ ) extended its power to most parts of what today is Indonesia, and to Mainland Southeast Asia, implementing specific traits of its rich culture. Did the Panji stories, being a popular literary genre of the time, make part of cultural export?
\end{abstract}

The paper then focuses on the Panji theme in Majapahit Java itself, particularly in the visual presentations in narrative temple reliefs. The significance of the depictions of Panji stories at Candi Panataran $\left(14^{\text {th }}\right.$ to $15^{\text {th }}$ centuries), the State Temple of Majapahit, allows an interesting understanding of the symbolic religious meaning of 
Panji. The essence of this symbolism is also manifest in the mountain sanctuary Candi Kendalisodo and in the Panji sculpture from Selokelir (mid-15 $5^{\text {th }}$ century).

In its final part, the paper addresses the role of the Panji theme in present-day revitalization of Javanese culture. The so-called "Panji Culture" ("Budaya Panji") has an enormous potential of strengthening the Javanese cultural identity. Possible ways of transfer and transformation of the Panji tradition within Java and within the larger Southeast Asian region are being discussed.

This paper was presented at the Seminar and Performances of a Shared Heritage: The Panji/Inao Traditions in Southeast Asia, organized by SEAMEO SPAFA on 2-6 March 2013 at the Bangkok Cha-Da Hotel and the Thailand Cultural Centre, Bangkok, Thailand. It is part of an upcoming collected edition of papers presented at the seminar.

Keywords: Java, Panji, temple reliefs, ancient art, Inao, Majapahit, intangible heritage

\section{Panji and Majapahit}

The Panji theme is known all over Insular Southeast Asia and Mainland Southeast Asia in a broad variety of forms of art and literature. It is generally believed that literary versions of the large corpus of Panji stories were taken to Mainland Southeast Asia through the extent of power of the Majapahit reign (Fig. 1). This economically and politically strong kingdom, centred in East Java and lasting from the end of the $13^{\text {th }}$ to early $16^{\text {th }}$ century has been considered as the "Golden Age" of Indonesia. The core part of its hegemony covered the areas which today form Indonesia (nusantara). Being the centre of trade in Southeast Asia, Majapahit played an important economic and political role in the region which also encompassed the implementation of its rich and unique cultural traits. One of these traits is supposed to be the Panji theme, which today is still manifest in traditions of performance and literature all over Southeast Asia, using the name "Inu", "Inao", "Panji". The Panji/Inao conference and festival in Bangkok presents these Panji traditions.

In the presentation of my original paper at the conference, I adhered to the common scholarly opinion that the Panji theme spread over Southeast Asia through Majapahit influence. The updated article, published now in the proceedings of the conference, raises the question if and to what extent this opinion can be maintained.

In order to understand the role of the Panji theme in Majapahit, we need to take a short look at the historical background of ancient Java. Prior to Majapahit, the political power in Java was centred in Central Java (since the $7^{\text {th }}$ century) with the reigns of the Buddhist Shailendra dynasty and the Hindu Sanjaya dynasty. Major manifestations of their politics, religion, culture and arts are the two famous temple complexes of the Buddhist Borobudur temple and the Hindu Prambanan temple. The relations and the extent of power of the two dynasties are somewhat obscure due to the lack of historical facts; only few stone inscriptions provide data which, however, are insufficient to draw a reliable picture. The East Javanese kingdoms of Kediri, Singosari and Majapahit are historically much better documented through stone inscriptions and written texts. The poem Nagarakrtagama (composed in $1365 \mathrm{CE}$ ), a eulogy on King Hayam Wuruk (1350-1389 CE), the ruler during the heyday of 
Majapahit, provides knowledge of the genealogies of the royal families and draws a lively picture of the time through descriptions of the king's travel, of administration, of the layout of the palace and the like. Hayam Wuruk was the king who substantially shaped Majapahit's power. Majapahit was the last Hindu-Buddhist kingdom before Islamic sultanates took over in the early $16^{\text {th }}$ century.

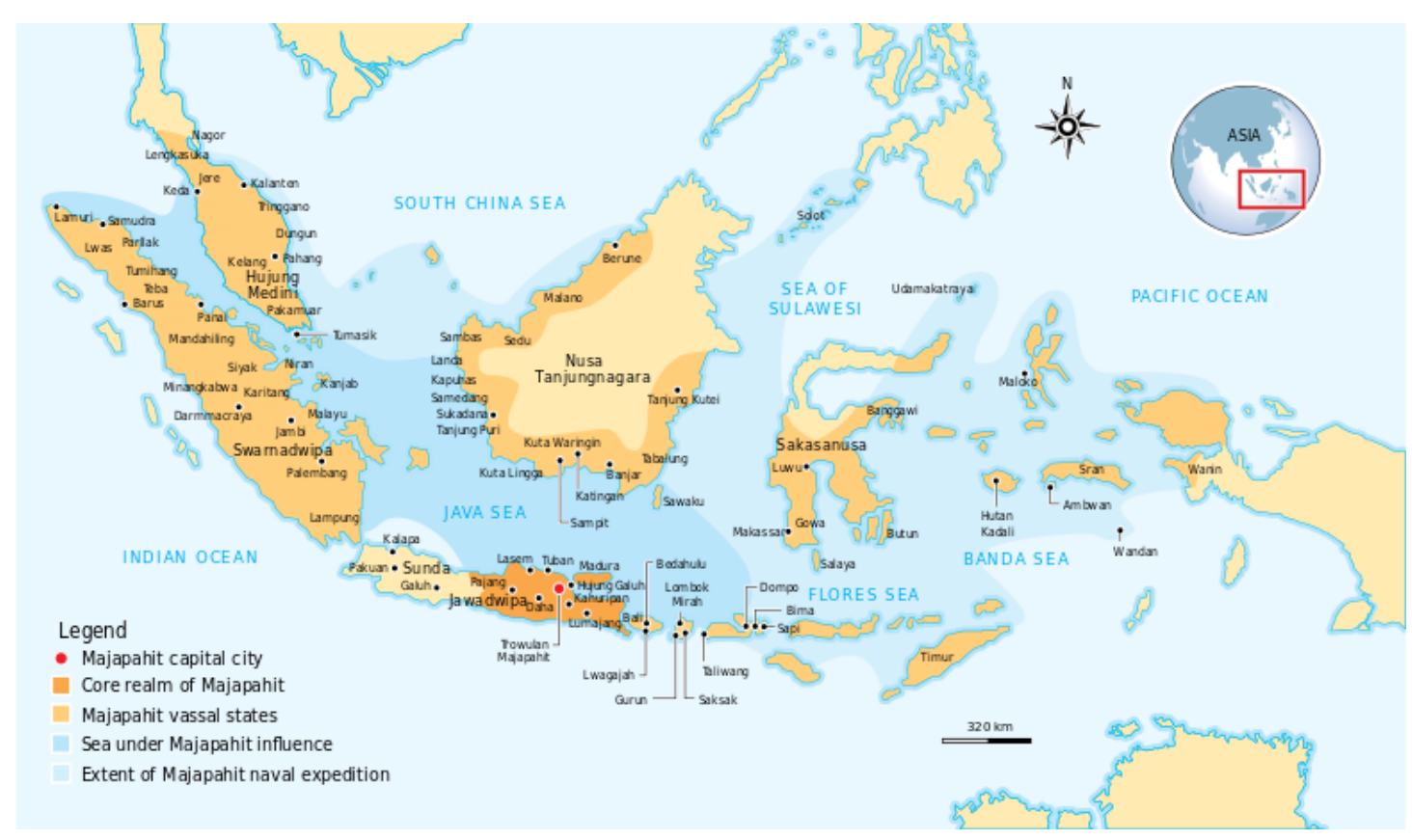

Fig.1 The Majapahit Empire (image by Gunawan Kartapranata, GNU Free Documentation License, Version 1.2)

The two historical periods, the Central and the East Javanese periods, display distinct forms of art. Art of Central Java is characterized by strong influence from India. Specific features of temple architecture and sculptural art display this impact of Indian art and culture: for example, the architecture of the Shiwa temple in Prambanan, the style of depictions in narrative reliefs, statues of deities all draw back on Indian models. A specific feature of Central Javanese architecture is the concentric temple layout which is conspicuous in the mandala shaped Borobudur. After the shift of power to East Java in the early $10^{\text {th }}$ century, the Hindu and Buddhist reigns of Kediri, Singasari and Majapahit developed new forms and styles of art. Particularly the Majapahit kingdom saw an innovative creativity in all parts of culture and arts, characterized as "local genius", going along with strengthening its political and economic power. The style of temple architecture changed to a linear layout and terraced buildings oriented towards a mountain; new styles of iconography of narrative reliefs covering the temple walls were created. Poetic literature flourished with both Indian based stories (kakawin) and indigenous stories (kidung). Language, metre, story plots and the protagonists of kakawin draw back on Indian Sanskrit literature, especially the Ramayana and the Mahabharata epics. Kidung poetry is created independently from Indian models and has a strong Javanese character. Both genres have a court setting, the protagonists being princes, princesses, kings and 
queens. Kakawin have a strong religious purpose; the poets of the kakawin declare their compositions to be a means to achieve union with the Divine. Kidung are more "down to earth", more related to daily life. Their theme is the struggle of young princes to become an accomplished kshatriya (a full member of the royal class), while the protagonists of the kakawin have already reached this status. This dichotomy of kakawin and kidung is mirrored in the terms "mythological stories" and "postmythological stories", keyed by Forge (1978) in his analysis of traditional Balinese paintings. Panji stories, as part of kidung poetry, are "post-mythological stories" par excellence: Through their encounter with common people and peasants on their search for each other, Panji and his beloved very much appeal to an average audience. Panji stories in literary as well as in visualized versions (at temple reliefs) represent one conspicuous example of Majapahit's creativity.

The Panji stories relate of Prince Panji from the Javanese kingdom of Jenggala, who is betrothed to Princess Candrakirana from Kediri. Before getting married, they are separated from each other by some circumstances. They walk and travel about the country, experience adventures, have amorous episodes and keep searching for one another. After having passed a number of obstacles and challenges, eventually they meet again and happily marry. There exist many versions of Panji stories, but the plot is always the same, and they all display a character of folk literature. The variation lies mainly in different circumstances causing their separation and in different kinds of adventures during their search for one another. ${ }^{1}$ Also, the names of the protagonists may be different: "Panji" is actually only a title to denote a prince, thus he appears by names such as Panji Asmarabangun, Panji Jayakusuma, Panji Semirang. Also Candrakirana is known by other names, such as Galuh, or Sekartaji. A "genuine" Panji story is not known. Panji stories evidently became very popular during Majapahit time, which is attested by the great number of their depictions in temple reliefs. Reasons for this popularity were both the religious and political meaning of the stories. Further down in the chapter on Candi Panataran, I will unfold and discuss the religious meaning of the Panji depictions in the temples.

Still, the political function needs to be taken into consideration. The struggle for uniting Panji and Candrakirana mirrors the political struggle between the historical kingdoms of Jenggala and Kediri, resulting from King Airlangga's division of his realm in mid- $11^{\text {th }}$ century. The unity of the realm and its inner peace was a major claim of the Majapahit king Hayam Wuruk in order to establish and strengthen the leading role of his kingdom as economic and political central power in the Southeast Asian region. Hayam Wuruk and other kings presented themselves as ideal kings. These political ideals are mirrored in the temples, in particular in the relief depictions of selected narratives. While the kidung stories, placed in the entrance part of a temple, thematize the preparation and struggle of young royals in achieving the status of a kshatriya and find a consort, the kakawin, placed in the sacred part of the temple, show the ideal king who has already become an accomplished kshatriya by both passing battles against enemies and by having a consort. The Panji stories - featuring Panji from Jenggala and Candrakirana from Kediri - symbolize the struggle and point

\footnotetext{
${ }^{1}$ Some titles of Panji stories: Panji Jayakusuma, Panji Angreni, Panji Wasengsari, Panji Wangbang Wideya. See other papers in this proceedings which discuss the literary genre of Panji stories.
} 
to the achievement of the union of the realm. This union meant peace, harmony and prosperity.

Scholars from various countries have been attracted by the theme of the Panji stories. Throughout the $20^{\text {th }}$ century, experts from the fields of philology, anthropology, history and archaeology have discussed the origin, the literary aspects, the historical relation and the aspect of art. While the literary aspect dominated the studies for a long time, the aspect of visual and performing art had, however, only got minor attention. A first intertextual look at the theme in terms of performing and visual art and of literature was presented by A. Vickers (2005) in his study of the Malat, the Balinese version of a Panji story. My study of the Panji reliefs on Majapahit temples filled the gap of taking the visual presentations in ancient Javanese art into account. ${ }^{2}$

\section{Panji in Candi Panataran}

My discussion of the Panji stories in Candi Panataran makes part of the outcome of my long-term research on the Panji reliefs and my interpretation of their religious meaning and function (Kieven 2013). ${ }^{3}$ Candi Panataran is assumed to be the State Temple of Majapahit; the Nagarakrtagama mentions it by the name "Palah". The temple complex was built and successively altered and extended during a long period between the end of the $12^{\text {th }}$ century and early $15^{\text {th }}$ century; the major parts date to the heyday of Majapahit during the $14^{\text {th }}$ century. The large complex consists of three courtyards (Fig. 2), a layout we still find today in Balinese temples (pura). Beyond this tripartite structure, there is a water place (petirtaan) in the very rear part of the complex. Walking along the linear layout of the temple, one proceeds from a less sacred part to the very sacred one. ${ }^{4}$ Panji stories are depicted in the first courtyard of the Panataran complex. They are carved on the walls of the so-called Pendopo Terrace, which served as the basement of an open hall (pendopo) used for preparing offerings to the temple and the gods.

\footnotetext{
${ }^{2}$ My publication (Kieven 2013) gives a detailed overview about previous research in the field of Panji studies. To mention but a few scholars and publications: Rassers 1922; Poerbatjaraka 1940, 1968; Berg 1954; Robson 1971; Vickers 2005. See the other papers in this publication that provide detailed information and discussion.

${ }^{3}$ The original topic of my research were the relief depictions of male figures wearing a cap as headdress who in many cases represent Panji. Other major objects of my studies on the cap-figure are the temples Jago, Surowono, Mirigambar and Kendalisodo, and the sculpture from Candi Selokelir.

${ }^{4}$ This system also applies to temple buildings which have a terraced architecture, where the visitor proceeds in a vertical way from the secular level on the lowest terrace to the sacred level on the upper terrace.
} 


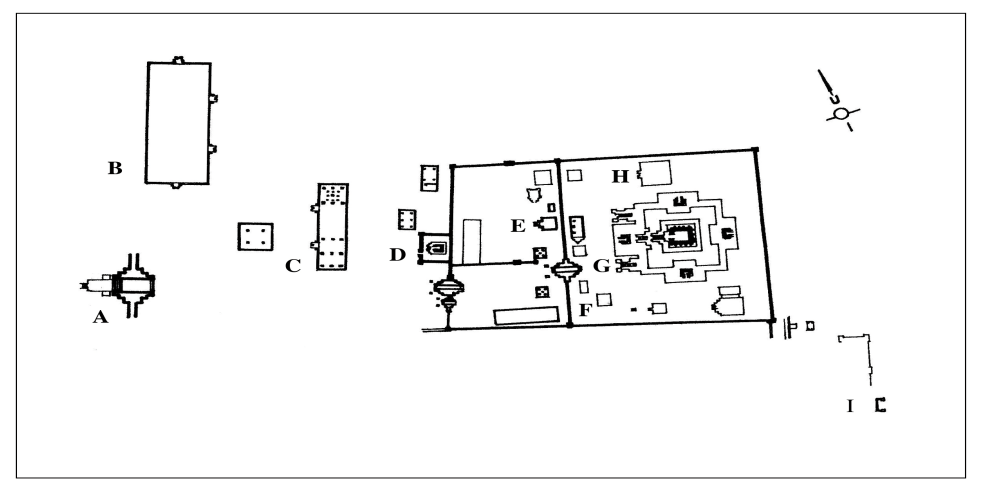

Fig. 2 The groundplan of Candi Panataran (based on Bernet Kempers, Ancient Indonesian Art. 1959:91)

In my research, I did not pursue the aim of identifying the depictions with known narratives. For me, it was important to understand the symbolic message underlying the visual depictions, which may differ from the symbolic message of the literary form of the story. Iconographically, Panji can be identified by the helmet-like cap, which is his usual headdress. I detected eight different stories which all display the three major elements of the literary plot of the Panji stories: (a) the separation of the two betrothed, (b) their search for each other and (c) their final reunion (Figs. 3, 4, 5, 6 ). Beyond this, the relief series display two additional major elements: (d) meeting a hermit and (e) crossing water (Figs. 7, 8). Meeting a hermit means seeking advice from a religious teacher. Water has the symbolic meaning of purification through the water of immortality (amerta), and the passage of water (tirtha) symbolizes the approach to a higher stage of spiritual wisdom. Both elements - (d) and (e) - do not play a comparable role in the literary versions of the Panji stories. In order to generally comprehend the symbolic meaning of relief depictions in a temple, it is important to look at the selection of the narrative and the depicted scenes, and their placement in the temple building or complex. These factors are a means to convey a certain message. The visual medium of presenting a narrative differs from the literary medium and allows another focus. I understand the combination of the five elements in the depictions of Panji stories, outlined above, as follows: Panji and Candrakirana who are struggling to meet again are seeking advice from religious teachers. In purifying themselves, they are prepared to achieve higher wisdom and eventually are ready to achieve their final union. I understand this final union, which is depicted in romantic and erotic ways, as a means in the esoteric path of achieving union with the Divine. This is known as a crucial aspect in Old Javanese kakawin poetry (Zoetmulder 1974: 172-85). ${ }^{5}$ The Panji reliefs only indicate this path; they do not carry it out. The final implementation is achieved in the sacred part of the temple.

\footnotetext{
${ }^{5}$ This path is the Tantric Kundalini path, an esoteric Hindu doctrine, which aims at the yogic experience of the union of the male and female principle, symbolizing the union of Siwa and Shakti. This experience leads to the deliverance of the soul. For the Tantric concept in Javanese ancient religion, see also Pott 1966.
} 


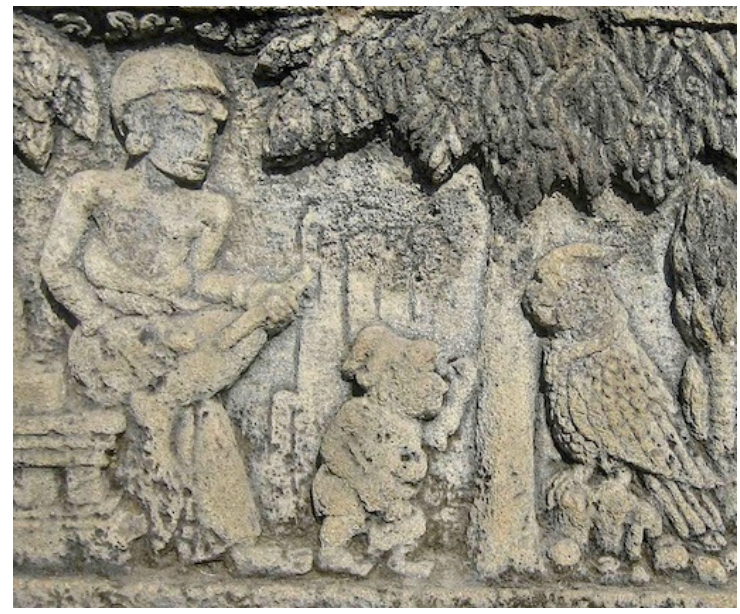

Fig. 3 Candi Panataran, Pendopo Terrace, Scene of a Panji story: Panji in a posture of longing (image by author)

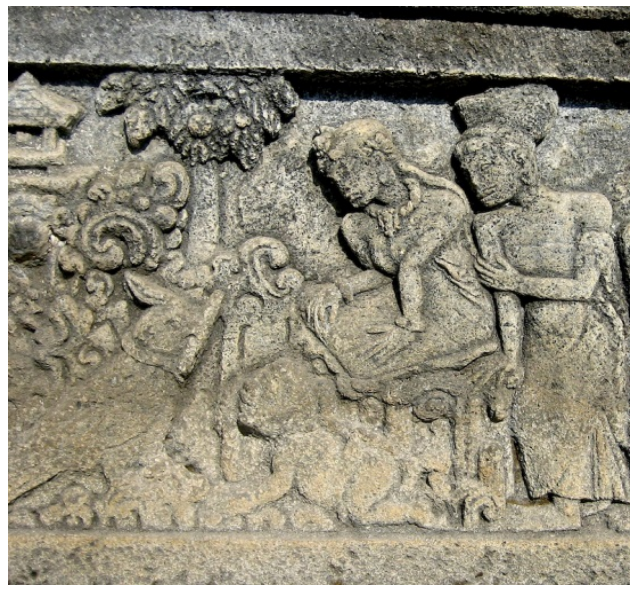

Fig. 4 Candi Panataran, Pendopo Terrace, Scene of a Panji story: Candrakirana in a posture of longing (image by author)

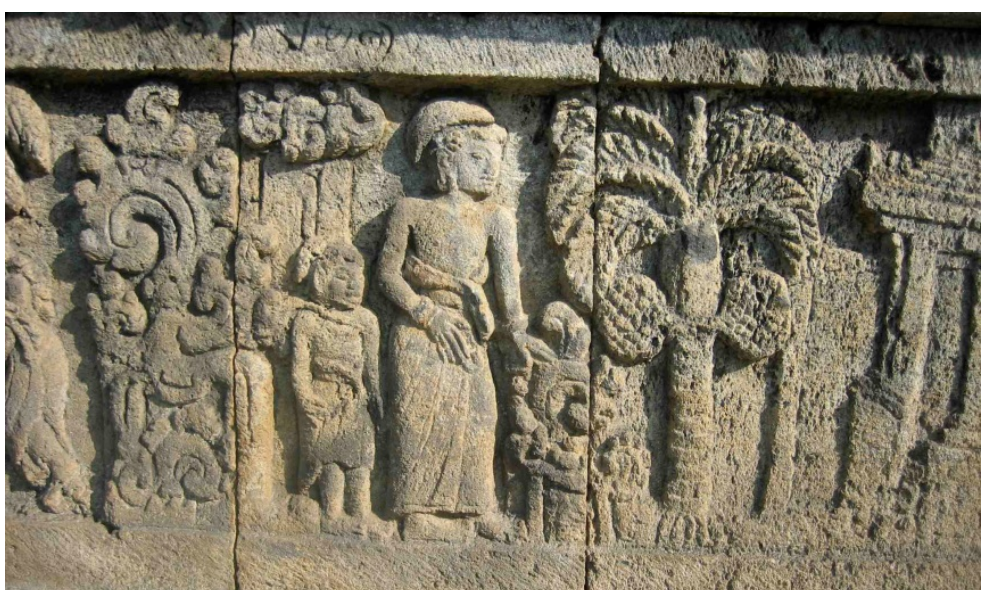

Fig. 5 Candi Panataran, Pendopo Terrace, Scene of a Panji story: Panji walking in search of his beloved (image by author) 


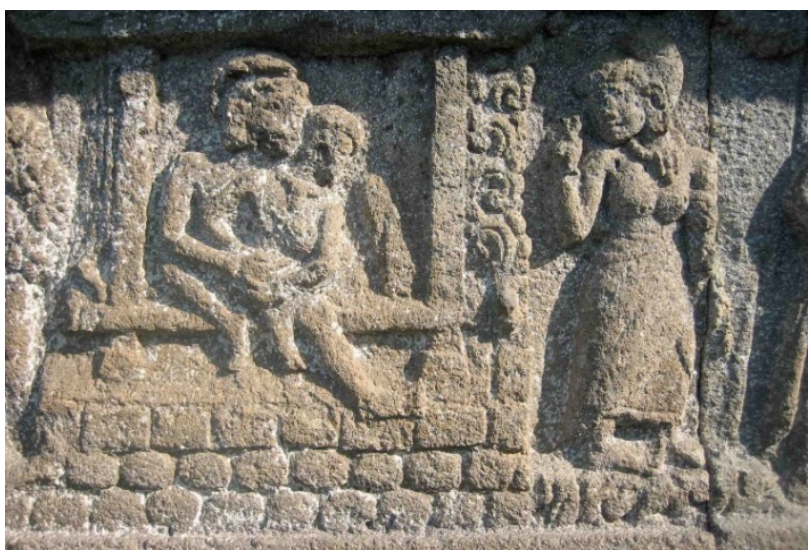

Fig. 6 Candi Panataran, Pendopo Terrace, Scene of a Panji story: Panji and Candrakirana in reunion (image by author)

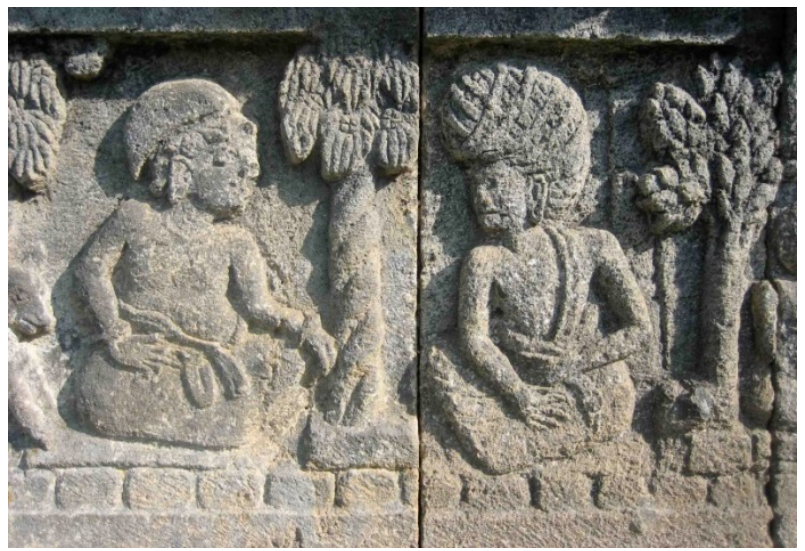

Fig. 7 Candi Panataran, Pendopo Terrace, Scene of a Panji story: Panji visits a hermit (image by author)

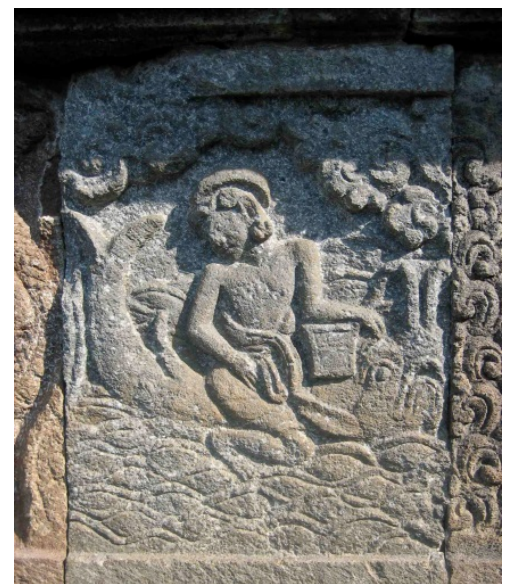

Fig. 8 Candi Panataran, Pendopo Terrace, Scene of a Panji story: Panji crosses water (image by author) 
The depictions of Panji stories display features of simple life, such as dress and attitudes of common people, thus transferring the folk character of the literary versions. In this way they act on a mundane level. Through this character and through their popularity at the time, the Panji stories very much appeal to the pilgrims and visitors who have just left their daily life and have entered the temple, they "welcome" and prepare the pilgrims to proceed to the sacred part of the temple representing the supramundane world. Panji has the role as an intermediary between the world of the humans and the world of the Divine.

Besides the Panji stories, the walls of the Pendopo Terrace display depictions of three other stories: the two kidung narratives Sang Satyawan and Sri Tanjung have the same characteristics as the Panji tales; the third story - the Bubukshah and Gagak Aking story - featuring the liberation of the soul, is the only story not having the Panji plot. The latter story is placed in the middle of the east side of the Pendopo Terrace; in this way, the Bubukshah and Gagak Aking story points towards the more sacred parts of the temple in its eastern parts.

The second courtyard of the temple complex has the so-called Naga temple as its major architectural construction. This building seems to symbolize the myth of the Churning of the Ocean relating the production of amerta by the gods. ${ }^{6}$ Purified by the holy water, the pilgrim can now proceed to the third courtyard dominated by the Main Temple. The walls of this building are decorated with relief series depicting episodes of Old Javanese kakawin narratives: the Ramayana (first terrace) and the Krishnayana (second terrace). The Ramayana depictions emphasize Hanuman and not Rama, the latter in fact being the hero of the literary form of the Ramayana kakawin. In the reliefs, Hanuman is ascribed the major role in the struggle of setting Rama's wife Sita free from her imprisonment by the demon king Rahwana. However, the final union of Rama and Sita in the story is not thematized in the reliefs. In the same way as Rama goes on in his path of setting Sita free and to reunite with her, Hanuman encourages and supports the pilgrims to go on in their path of seeking wisdom. He acts as an intermediary between the human world and the world of the Divine, similar to Panji, however on the higher level of the kakawin genre. The following relief depictions of the Krishnayana kakawin take up the struggle for the union of man and woman, in this case Krishna and his wife Rukmini. By achieving this union, depicted in the final part of the series, Krishna becomes the accomplished kshatriya. More than that, I understand this union as an indicator to the aim of the Tantric path underlying the allencompassing concept of Candi Panataran. It is remarkable that the two final depictions show water: the purification and the passage to a higher stage of wisdom, same as in the Panji stories on the Pendopo Terrace. The aforementioned dichotomy and hierarchy of the literary kidung and kakawin genres is mirrored in the placement of the depictions, in the first and the third courtyard respectively.

Eventually the pilgrim proceeds to the small water place (petirtaan dalam) behind the third courtyard. The walls of this petirtaan are decorated with reliefs of Tantri stories (animal fables) and with large carved figures in a standing posture. The legs of these

\footnotetext{
${ }^{6}$ As related in the Old Javanese texts Adiparwa from the late $10^{\text {th }}$ century and Tantu Panggelaran from the $16^{\text {th }}$ century.
} 
figures reach below the surface of the water; I identify one of the figures to represent Panji. The other figures would represent Candrakirana and two companions of Panji Kertolo and Brajanata -who frequently appear in the literary forms of Panji stories and also in Panji reliefs. Following my interpretation of Panji as an intermediary, I understand his depiction in this location as a symbolic invitation to enter the water. I think that indeed this holy water place was the most sacral part of the whole temple complex. $^{7}$

As mentioned above, the placement of the relief series in the temple complex follows a certain hierarchy. "Post-mythological stories" (kidung) appear in the entrance part while "mythological stories" (kakawin) are placed in the rear part. Also, the styles of the relief depictions differ from each other, mirroring the dichotomy between kidung and kakawin: while the former are characterized by simple dress and by the cap which is Panji's specific headdress, the latter show the heroes in a wayang-like style, characterized by more elaborate dress and by the supit urang (the crab-claw headgear, which is still known today as headgear of Balinese wayang figures). ${ }^{8}$

The placement of the Panji figures in the petirtaan dalam in fact seems to contradict the aforementioned principle of the hierarchy between mundane and sacred parts of a temple. The appearance of Panji in this sacral part of the Panataran temple complex makes evident that he was indeed considered appropriate to implement his role as a guide to the esoteric realm. This role was obviously commonly established and acknowledged at the time.

The fact that popular stories such as Panji stories with their daily-life character and lacking the sacral connotation of the kakawin stories, were chosen for depictions in a temple and in particular at prominent locations at a temple, attests to their high esteem by society, by religious circles and by royalty. It also suits Hayam Wuruk's policy of approaching the rural people during his travels through the countryside and in this way manifesting his claim to be a just and caring king. Candi Panataran as State Temple was of course a major place to manifest the political claim of the union of the realm; the Panji stories were used as a symbol of the struggle for this union. It is remarkable that the depictions of Panji stories do not display any war or battle scenes while the literary versions do! It seems that the authorities who built the temple did rather emphasize the religious aspect of the Panji stories in order to legitimize the king's leading religious role after having gone and passed the spiritual path following the ideal of Panji. The kakawin depictions on the Main Temple, including battle scenes, emphasize the accomplished and ideal king who is capable of protecting the people, also by warfare.

\footnotetext{
${ }^{7}$ This preliminary interpretation still requires further investigation. We do not know if the place was visited prior to entering the temple complex, or only after having proceeded through the whole precinct. For the complex understanding of the esoteric Tantric path in Candi Panataran, see Kieven 2013: 232-9.

${ }^{8}$ This principle underlies all temples with a hierarchical layout, be it in a linear form as in Panataran, or in a vertical order such as for example in the terraced structure of Candi Jago.
} 


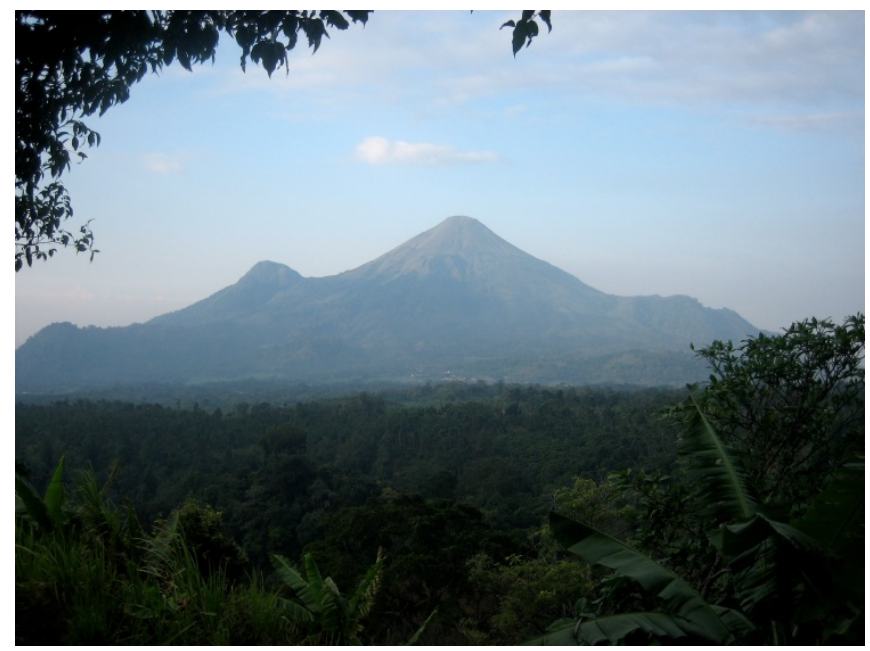

Fig. 9 Mount Penanggungan, view from the south (image by author)

\section{The Panji Reliefs at Candi Kendalisodo}

The mountain sanctuary Candi Kendalisodo is located on the slopes of Mount Penanggungan (1653 m) (Fig. 9). This mountain has over the centuries been considered as a conspicuous sacred place: its shape of having one peak surrounded by eight hills corresponds to Mount Meru, the seat of the gods in Hindu mythology. More than 130 sanctuaries have been detected on the slopes of Mount Penanggungan. ${ }^{9}$ Several of these sanctuaries are decorated with reliefs depicting Panji stories. ${ }^{10}$ Candi Kendalisodo is one of the most beautiful and rather well conserved sites. It encompasses a terraced sanctuary decorated with Panji reliefs, and a hermitage whose walls originally were decorated by depictions of the Arjunawiwaha and the Bhimasuci. The Panji story is depicted in four beautifully carved episodes full of romantic and erotic atmosphere. Three of the major aspects of Panji depictions, mentioned earlier in my discussion of Candi Panataran, are visible in these reliefs: the separation of the two lovers; their union in a romantic and erotic way, Panji holding his beloved on his lap and playing the musical instrument vina (Fig. 10); crossing of water. In the final panel Panji indicates with his hand towards the hermitage which the pilgrim would approach, after having visited the sanctuary. Panji acts again as the guide for the pilgrim to proceed to the place of achieving higher wisdom by a spiritual teacher, in this case in a "real" hermitage. The Arjunawiwaha and the Bhimasuci, both of them being based on Indian epics, depict and symbolize the struggle of Arjuna and Bhima in achieving insight into Higher Knowledge. Again, same as in Panataran, the selection of scenes and their placement follow the hierarchy of the literary genres of the narratives - kidung and kakawin. Candi Kendalisodo is, in a way, the concise version of Candi Panataran.

\footnotetext{
${ }^{9}$ The independent researcher Hadi Sidomulyo has recently raised an updated inventory, differing from the earlier one by Van Romondt (1951) counting 81 sanctuaries.

${ }^{10}$ The most beautiful reliefs are those of Candi Kendalisodo showing four panels with romantic depictions of the journey of Panji and his beloved.
} 


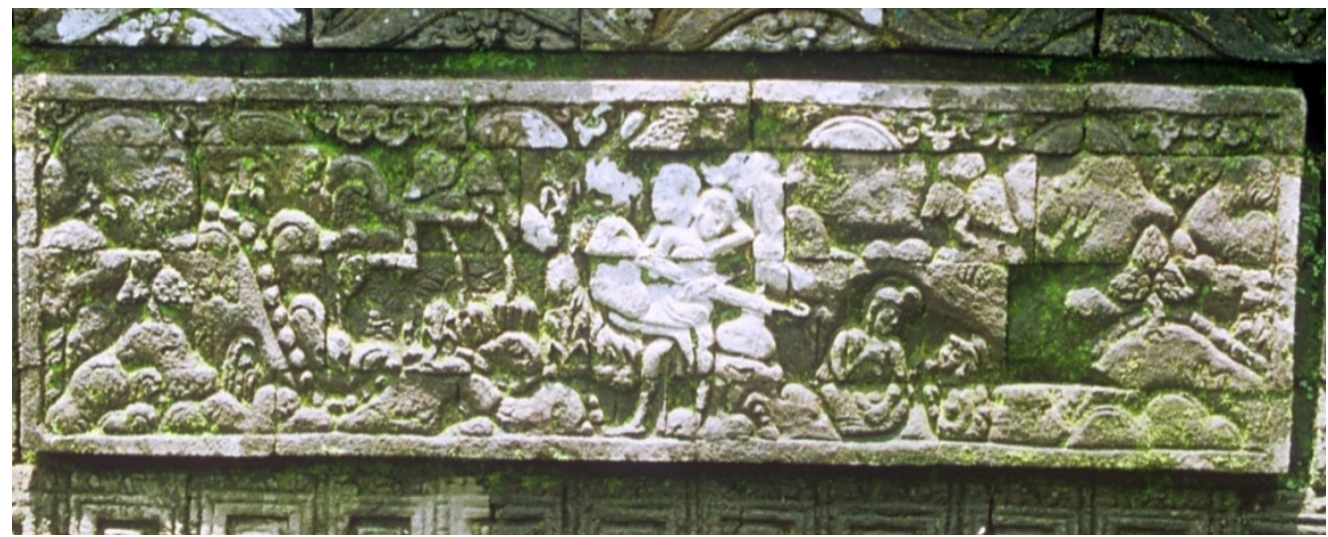

Fig. 10 Candi Kendalisodo, Scene of a Panji story: Panji holds his beloved on his lap, playing the vina (image by author)

Very sadly, the Panji heads in two of the panels were damaged in recent time (Fig. 11), while all of the three reliefs on the hermitage walls were already destroyed years and even decades ago. ${ }^{11}$

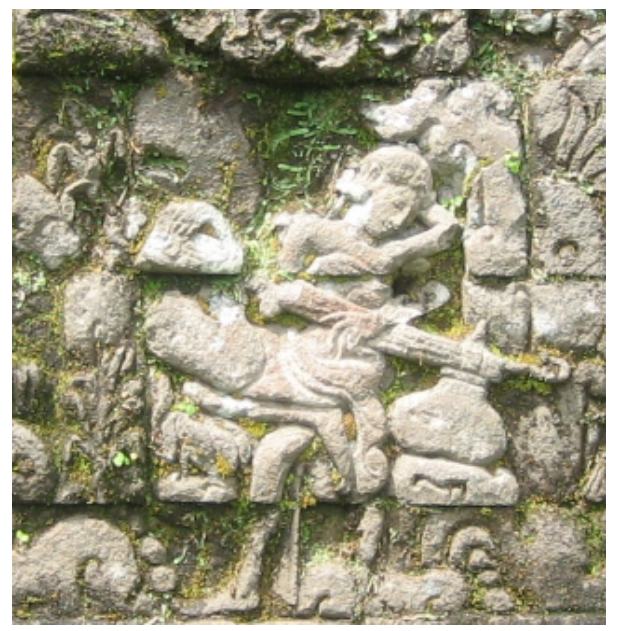

Fig. 11 Candi Kendalisodo, Detail of a scene of a Panji story: Panji holds his beloved on his lap, playing the vina (image by author)

\section{The Sculpture from Candi Selokelir}

The climax of the popularity and the symbolic meaning of Panji were reached in the Panji sculpture (circa $1450 \mathrm{CE}$ ) from Candi Selokelir, a small sanctuary located on the foot of Mount Penanggungan. ${ }^{12}$ The sculpture (height: $125 \mathrm{~cm}$ ) depicts Panji with

\footnotetext{
${ }^{11}$ OD-photos, kept in the archives of the Kern Institute (now University Library) in Leiden, show the original reliefs in full detail.

${ }^{12}$ This sculpture is at present kept in the Library of the Fine Arts at the Institute of Technology in Bandung (ITB). A replica has recently been made by the National Museum in Jakarta.
} 
the typical iconographic element of the cap (Fig. 12). ${ }^{13}$ His clothes are simple; he has hair in the armpits, which characterizes him as a common person. Additionally, however, the image displays features being typical of a deity: standing on a lotus cushion, having a caste cord (upawita) and holding a lotus bud in his hands in front of the chest. I consider this as an evidence that Panji was worshiped like a deity without, however, being a deity himself. It seems that Panji's esoteric character as an intermediary was well-understood by spiritual seekers at the time. The location of the sculpture on the foot of Mount Penanggungan even enhances this meaning, since further up the mountain there are dozens of sanctuaries and hermitages such as Candi Kendalisodo, which were visited by pilgrims. Prior to the climb on the mountain, the pilgrims would have "received" guidance from Panji.

\section{Female Sculpture from Mojokerto}

An ancient Javanese statue representing a female figure (height: $105 \mathrm{~cm}$ ) is kept at the National Museum in Jakarta. The label indicates its original place as Mojokerto in East Java, $14^{\text {th }}$ to $15^{\text {th }}$ centuries. Based on iconographical analysis I conclude that this image may have been meant to depict Candrakirana. Details such as the softness of the body, specific pleats of the garment, the shape of the fingers, the shape of the feet and toes and their decoration display a style which is conspicuously similar to the Panji sculpture. We may assume that both images were carved in the same workshop. Earlier, I interpreted both figures as the couple Panji and Candrakirana. After recent deeper research, however, I detected from a photo taken in 1915 at the site of Candi Selokelir, ${ }^{14}$ that another female sculpture once accompanied the Panji sculpture. This female sculpture has vanished. ${ }^{15}$ Based on the existence of two other Panji figures, one from Grogol (dated $1413 \mathrm{CE}$ ) and another one kept in the Museum Prambanan, both with provenance from Mount Penanggungan area, I conclude that there must have existed more Candrakirana sculptures forming counterparts of Panji sculptures. ${ }^{16}$ Thus, the concept of the union of Panji and Candrakirana, outlined in the relief depictions, did also hold for the sculptural art.

\footnotetext{
${ }^{13}$ Earlier publications on the Panji sculpture incorrectly mention the height as $150 \mathrm{~cm}$, drawing back on Stutterheim 1936a,b. Also my publication of 2013 mentions the wrong height.

${ }^{14}$ Photos OD-2190, 2191, kept in the archives of the Kern Institute (now University Library) Leiden.

${ }^{15}$ Kieven 2016: "Panji and Candrakirana lost in separation" in: Amerta, Pusat Arkeologi Nasional, Vol. 34, 1, June 2016: 31-48. More Panji related items to be researched in the future are, for example, magic coins presenting depictions of Panji and Sekartaji (Cribb 1999).

${ }^{16}$ The Grogol figure is documented in Stutterheim 1935: 142; the Prambanan figure is mentioned in Van Romondt 1951: 11. I am grateful to Hadi Sidomulyo for bringing this latter figure to my attention.
} 


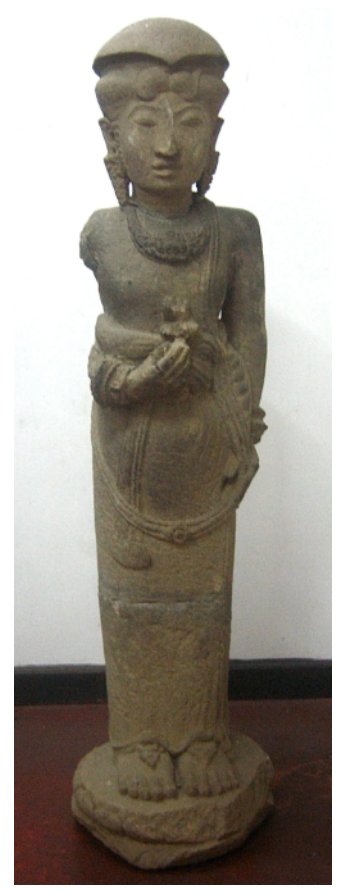

Fig. 12 The Panji Sculpture from Candi Selokelir, ITB Bandung (image by author)

\section{Question: Panji's Spread in Southeast Asia in the Context of Majapahit Expansion?}

As mentioned above, general scholarly opinion holds that the spread of the Panji theme in other parts of Southeast Asia beyond Java happened along with the expansion of Majapahit's politics (Vickers 2015). So far, only few scholars have discussed this topic at all. It is the merit of the conference on Panji/Inao traditions in Southeast Asia to give attention to this rich cultural heritage throughout the whole region. Through a recent $\mathrm{PhD}$ thesis ${ }^{17}$ and the conference presentations by colleagues from Thailand, Laos, Vietnam, Cambodia, Malaysia about their points of view and about historical facts, I now come to doubt the Majapahit theory. In Thailand the Inao-Bussabha story $^{18}$ was written by King Rama II (ruled 1809-24), drawing back on earlier stories, and became popular in poetry and in performing arts; it is also presented in the murals of the Buddhist temple Wat Suthat from the mid- $19^{\text {th }}$ century in Bangkok (Robson 1999). It seems that Thailand played a major role in spreading the Inao tradition to other parts of Southeast Asia particularly during the $19^{\text {th }}$ century, as being communicated in a number of conference papers. The significant common trait of all versions of Inao stories and dance choreographies is the plot of Inao as a prince from the kingdom of Jenggala and Bussabha as a princess from Daha/Kediri, ${ }^{19}$ their separation, their adventures and struggle and their final reunion. The fact that the names Jenggala and Daha, and in some versions also the name of Java, are maintained, shows that the geographical-historical roots of the narrative were indeed

\footnotetext{
${ }^{17}$ Davisakd Puaksom 2007.

${ }^{18}$ In Thailand and other countries in Mainland Southeast Asia the name "Inao" is used for "Panji", and "Bussabha" for "Sekartaji".

${ }^{19}$ It was interesting to hear that Cambodian people understand the name "Daha" as "Doha" and thus interpret the Inao stories as having their origin in Qatar, with the capital Doha.
} 
known and that Java was highly esteemed. ${ }^{20}$ However, today this knowledge seems to have fallen into oblivion, as became clear in this conference. Research is still required on the question of the process of adoption of the Panji theme in Mainland Southeast Asia - whether it happened via Majapahit or during later times, or in interconnected ways. This means that a large field is still open for future research.

\section{Panji Culture in Indonesia Today}

The revitalization of the Panji theme today has to be seen against the background of the changes of Javanese attitudes towards their culture and their cultural heritage. ${ }^{21}$ Indonesian society is experiencing major influence by Western concepts and orientations and consequently undergoing remarkable social and cultural changes. In particular the young generation wants to be "modern", which they, to a large degree, identify by using digital equipment and social networks such as Facebook and Whatsapp, whenever possible in the newest versions. General mainstream and political attitudes have increasingly considered adat, the Indonesian term for traditional practices and behaviour, as antiquated and as objecting modernity. The impact is that interest in own cultural roots has been diminishing over the decades. A conspicuous example is the shadow play wayang kulit: traditional wayang being performed throughout the whole night and having a ritual character, strongly decreased since the 1990s in the heartlands of Javanese arts which are the cities Yogyakarta and Surakarta. On the other side, teaching of wayang, classical dance, gamelan music and other traditional performing arts have entered the curriculum of the academic institutes of art in standardized forms, replacing traditional ways of learning from a personal teacher emphasizing the ritual character (Hughes-Freeland 2008). The acknowledgement of wayang kulit as Intangible World Heritage by UNESCO in 2008 has certainly contributed to a higher appreciation by Javanese and Indonesian society. Still, it is at present not clear if these attempts aim at keeping the spiritual or "only" the technical, artistic, and entertaining quality of the performances.

Another change of Indonesian society today is caused by the increasing development of orthodox Islamic values in Indonesia, impacted by influence from Middle-East countries. $^{22}$ Indonesian Islam has always been considered as moderate. The early establishment of Islam in Java in the $16^{\text {th }}$ century was based on mystic Sufi philosophy with the essence that a human can seek and achieve union with the supramundane; this suited well the pre-Islamic Hindu-Buddhist beliefs. The esoteric concept of Old Javanese religion and its manifestation in literature and art was carried on during the Islamic period. Islam in Java developed in two major lines: the way of mystic beliefs and practices labelled as "kebatinan"/"kejawen", and the orthodox Islamic way. ${ }^{23}$ In recent time orthodox leaders have labelled traditional practices as superstitious and thus as pagan (musrik) and have threatened them. In 2011 a wayang kulit performance in the region of Surakarta was attacked by a fanatic Islamic group. It seems that such judgements and sanctioning already shape the way of thinking of large parts of the population today. People feel intimidated to practise traditional

\footnotetext{
${ }^{20}$ See the PhD thesis by Puaksom.

${ }^{21}$ For future research: these attitudes towards culture have to be discussed within the discourse on Intangible Heritage (see for example Laurajane Smith 2009).

${ }^{22}$ Andrée Feillard 2010.

${ }^{23}$ Mulder 1998; Ricklefs 2006.
} 
rituals such as ancestor worship by bringing offerings to the graves. However, there are also counter-reactions: in September 2013, there was strong protest by moderate and in particular young people in Yogyakarta after a group of fanatics damaged the graveyard of the Sultan's family in Imogiri, a place which is highly venerated by the inhabitants of Yogyakarta. ${ }^{24}$

A third major impact is tourism: traditions of intangible as well as tangible heritage are presented and performed in a "soft" and entertaining way meeting the needs and wishes of tourists, by sacrificing inner values. Some examples: Shortened versions of wayang kulit performance do neglect the ritual and spiritual aspect. The Buddhist Borobudur temple lacks introduction into the religious and sacral function and has become a mere tourist sightseeing object. Implementation of touristic programmes by official agencies often neglects or ignores local people. The main aim of the tourist industry is the economic outcome and not the appreciation and maintenance of the values (Hitchcock 2010: 18-9).

To summarize, Western globalization, radical Islamic influences and tourism are an enormous challenge for society and in particular their attitudes towards their cultural heritage and traditional practices. The establishment of the UNESCO Convention for the Safeguarding of Cultural Heritage in 1972 and the later Convention of Intangible Heritage in 2003 has immensely contributed to an increased and strengthened awareness and appreciation by society of their local heritage and tradition and a willingness to preserve cultural properties. Actually, actors on grass-roots level - in particular intellectuals, artists, cultural activists - did already earlier start initiating concepts and programmes of revitalizing local traditions, as a counter-reaction to the menaces of traditional values. It seems that official stakeholders put the emphasis on safeguarding traditions, for the sake of preserving from extinction, by means of popularization, in particular through tourism, while some informal groups and actors look more at strengthening the essence and inner values of traditions such as spiritual, ritual, and religious meanings.

Within these complex developments and changes, "Budaya Panji" (Panji Culture) plays a significant role. Throughout the last two decades, a process of revitalization of the Panji theme has been developing. It was originally the late Suryo Wardhoyo Prawiroatmojo (1956-2013), an environment activist, who, since the mid-1990s became interested in the Panji tradition within his concepts of environment education. His impetus lay on strengthening knowledge and awareness by local people of their own culture and tradition, in particular of forgotten agricultural rituals connected with the Panji stories. The pride of the local rich culture would then impart an attitude of appreciating and preserving culture, including the environment. In 2004 Suryo Wardhoyo Prawiroatmojo assembled individual actors - such as artists, dancers, historians, archaeologists - who, by various reasons, had developed interest in the theme of Panji. A first outcome was the Panji Festival in 2007 consisting of art, academic and educational programmes. ${ }^{25}$ Through ongoing personal contacts and

24

http://regional.kompas.com/read/2013/09/18/1732098/Warga.Yogya.Kecam.Perusakan.Makam.Cucu. HB.VI

${ }^{25}$ The academic seminar was conducted by Universitas Merdeka in Malang. 
increasingly on a broader level of Javanese community, activities in the field of "Panji" were further developed: in fields of education, environment, ritual, art, performance, seminars, and research. Besides the preservation of traditional forms, since 2015 there has been a rapid development of transformation and application in contemporary forms of art and ritual. All these activities and processes have been enacted on a grass-root level by enthusiasts and private groups. Only recently, the Panji related activities entered official stages run by governmental institutions. In 2016 the National Library in Jakarta submitted a nomination form to the UNESCO: 71 Panji stories manuscripts kept in the archives to be acknowleded as "Memory of the World" (Fig. 15). ${ }^{26}$ In an appendix, I present a list of events and activities since 2004.

\section{The Potentiality of the Panji Theme Today}

The specificity of the Panji theme makes it a conspicuous object of revitalization of cultural heritage. Major aspects are: 1) creativity, 2) folk-like character, 3) moral ideals and 4) religiosity. 1) It demonstrates the local creativity and the uniqueness of ancient East Javanese - and in particular of Majapahit - art and literature, carried on in creations of local narratives and unique forms of performing arts, including wayang beber, wayang topeng, etc. ${ }^{27}$ 2) The fact that these forms are enacted in the sphere of common people, makes the Panji theme appropriate to raise pride of local people. Through their folk-like character, the Panji stories and Panji arts go beyond the famous "big" arts, such as wayang kulit, glamorous Ramayana dance performances, batik, the famous temples in Central Java and the like. (3) The content of the Panji theme provides ideals of human attitude towards life: the struggle for an intended aim; the acceptance of hindrances in this process, and the self-confidence in mastering them; the loyalty to a once given promise and loyalty, eventually achieving the aim which yields harmony and peace. The way of undergoing this struggle is simplicity, not overacting, and sticking to the given conditions. (4) In its utmost essence, Panji points to spirituality, which is embedded in the achieved harmony. Human beings, who are struggling to master and to understand life, can start on a basic level and, by mastering step by step and following advice from teachers, they may proceed to an understanding. They can learn from Panji, who acts as their guide. This is the process I have outlined in the symbolism of the temples Panataran and Kendalisodo.

Agricultural fertility rituals did indeed enact this symbolism of harmony, but they got extinct. Also, the original spiritual aspect of mask dances (Fig. 13) is menaced to fall into oblivion. Exploiting all four mentioned aspects of the Panji theme may impart a crucial contribution to strengthening pride about local traditions and become a means not to lose roots and identity. It is to be hoped that understanding and practice of this specific local wisdom will produce an ongoing "living heritage" rather than becoming a "dead" heritage such as the Borobudur which is cut off its sacral and historical meaning. ${ }^{28}$

\footnotetext{
${ }^{26}$ In the meantime the application has been extended to incorporate collections of Panji manuscripts in the archives of Leiden University (Netherlands) and of the National Library of Malaysia. The decision by UNESCO is expected for October 2017.

${ }^{27}$ Wayang beber = paper scroll drama; wayang topeng $=$ mask dance. Both of them are assumed to originate in Majapahit time.

${ }^{28}$ Along with the growing attention of Majapahit history paid by researchers, artists, politicians and society, Candi Panataran as the State Temple of Majapahit has attracted increasing interest. The temple compound has recently been acknowledged as a cultural heritage site by the province of East Java. A
} 


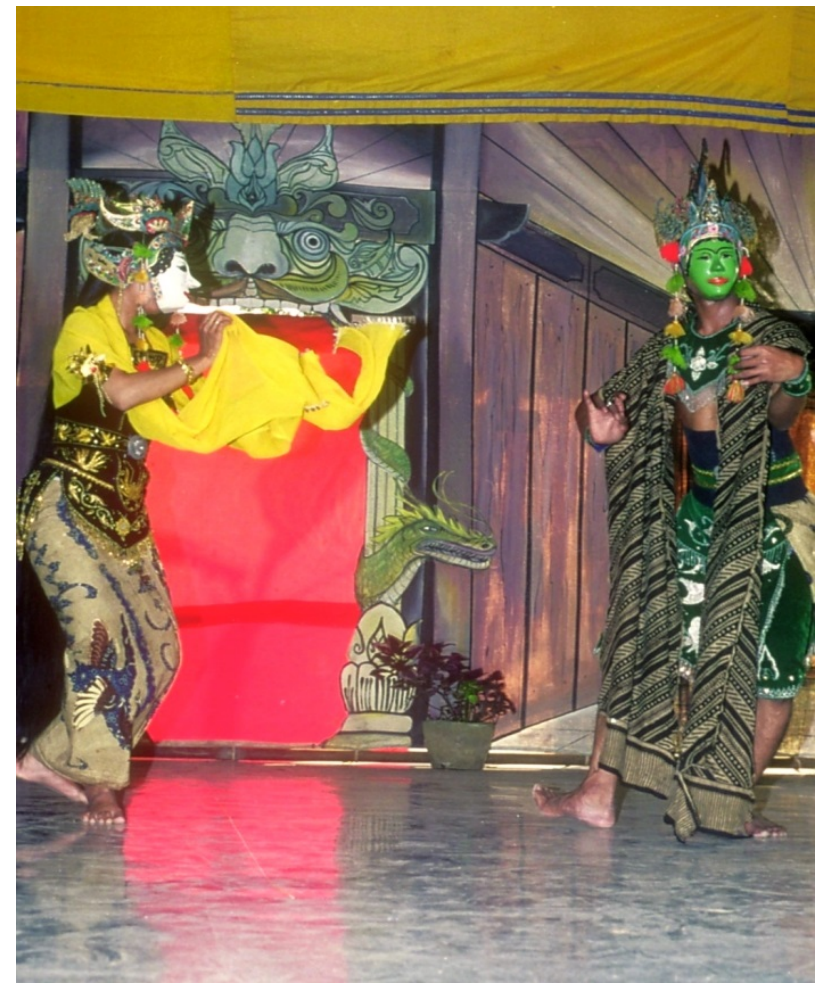

Fig. 13 Performance of mask dance wayang topeng, Malang (image by author)

"Creativity" becomes a keyword in the ways of enacting the Panji theme. Panji himself is a creative figure who, in the stories, acts as a master in composing music, poems and other forms of art. The Panji theme is a medium par excellence which allows implementing creative processes today, same as it did over the centuries. Ways and forms of application are manifold: revitalizing traditional forms and creating new forms of performances, art, literature and rituals; educational programs; discussions and research on the various aspects. There is a broad scale ranging from entertainment on one edge to spiritual enactment on the other edge, covering interconnected forms and media and offering huge potential of implementation. It is also important to involve local people in creating own ways of making use of the Panji theme and not to leave them as a passive audience to be entertained. The specific and unique nature of the Panji theme, the simplicity and the daily-life character, can be used as an essence for projects in villages and rural communities. Examples are the wayang beber workshop and the transformation of wayang beber in contemporary art, described further down.

The development and process of "Budaya Panji" do also bear critical aspects: throughout the years various groups or towns have claimed to "own" genuine aspects 
of Panji. ${ }^{29}$ However, instead of competition, synergetic attitudes in bringing together and sharing the respective specificities will hopefully produce beneficial and valuable outcomes on many levels in the future. Tourism and big events of Panji Culture may certainly enhance the knowledge of the Javanese people about their rich Panji tradition; however, emphasizing the entertaining qualities of performances to attract large audiences bears the risk of neglecting and loosing the inner values of this multifaceted cultural heritage. The focus on artistic qualities may have the same effects. ${ }^{30}$

The outlined forms of revitalization and transformation in Java can be considered as models and input to stimulate similar processes in other countries in Southeast Asia. So far the Ramayana, being imported from India, has been considered and exploited as the common trait of Southeast Asian culture. The Panji theme, being created in Java and having no roots in Indian culture, nor the Western or Arabic world, did further develop in Southeast Asia and became a specific cultural trait of the region. Thus, the Panji Culture has the potential to raise and increase self-consciousness, selfconfidence and cultural identity of the population of the whole Southeast Asian region, being important in an era of globalization and radical religious dogma. ${ }^{31}$

\section{An Example of Revitalization, Transformation and Application of the Potential of the Panji Theme: Wayang Beber}

A description of an event in August 2007 in Trawas, East Java (Fig. 14):

Imagine an evening after $6 \mathrm{pm}$ in Java when it's dark and warm. There is a mild wind blowing so that you don't get sweaty. We are near Trawas on the lower slopes of Mount Penanggungan, $50 \mathrm{~km}$ south of Surabaya, the capital of the Indonesian province of East Java. You hear children singing, one of them with a raised voice sounds like narrating a story. Torches flicker in the darkness. Attracted by the voices and by the light, you get closer and see two children holding and slowly unrolling a paper scroll, with depictions of coloured figures, landscapes, houses, animals. One of the figures wears a helmet-like headdress. Another child sits in front of the paper scroll, points with a little stick on the depicted figures and, like a shadow puppet player (dalang), narrates the story behind the depictions. About 10 other children with a soft voice sing their songs, accompanying the dalang. Next to the group stands a Javanese man, smiling and obviously being very happy with the event. Suryo Wardhoyo Prawiroatmojo from Trawas has enacted this spectacle in August

\footnotetext{
${ }^{29}$ The city and district of Kediri proclaim to be "Kota Panji" and "Bumi Panji" (Panji-city and Panjiarea); Blitar - represented by the Arts' Association of the district - initiated Panji Festivals and published the journal Sahabat Panji; Malang presents itself as the home of wayang topeng performance centre; Pacitan is about to discover the wayang beber as the roots of the Panji tradition.

${ }^{30}$ Compare the statement above, related to the development of classical arts in the classical Central Javanese tradition (Hughes-Freeland 2008).

${ }^{31}$ The author of this paper is currently doing research on the role of the Panji theme as an intangible heritage, based on a documentary of traditional forms of presentations and of the activities of the "Panji Culture" through the last decade. The outcome will be a book in Indonesian language, planned to be published in 2017: "Proses revitalisasi tradisi Panji dan transformasinya." (= Process of revitalization of the Panji traditions and their transformation).
} 
2007. His idea is to initiate a revival of wayang beber, an old traditional way of performing Panji stories. Wayang beber having its origin in East Java is nearly extinct. There still exist a few rolls in the region of Pacitan (East Java) and Gunung Kidul (Central Java near Yogyakarta) which for many years have not been performed any more. No child in common society would ever hear about wayang beber. But now here in Trawas there are a few children acting as dalang and as singers, obviously being very happy and enjoying themselves. Older people from the village in the audience look touched and smile at each other. They seem to be proud of this old tradition which was part of their youth and ever since seemed to be lost.

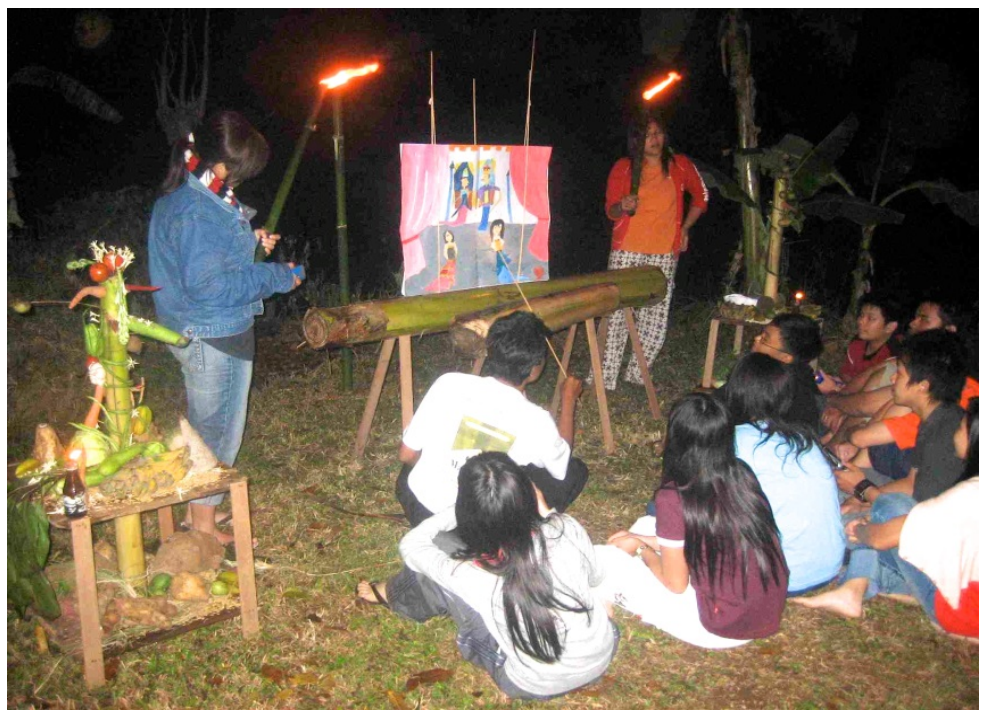

Fig. 14 Workshop of wayang beber in Trawas 2007 (image by author)

During the last years new forms of revival of wayang beber emerged. After a long gap of non-activity, three dalang (puppeteer) who were instructed by the late Pak Sarnen and Pak Mardi, continued the old tradition. Two of them practice the traditional way. Rudy Prasetyo gave a traditional performance using duplicates of the original set at the Panji/Inao-Festival in Bangkok 2013. Another young man created a contemporary form and has been performing daily with a group of musicians (called Wayang Sakbendino). The contemporary artist Dani Iswardana from Solo (Surakarta) draws back on wayang beber and integrates it in his creative work. Through international exhibitions and through the group wayang beber kota he communicates his art both to a national and international audience. Personal contacts between a number of artists and using synergetic effects have yielded collaboration between the groups Wayang Beber Kota, Wayang Sakbendino, Wayang Beber Metropolitan (based in Jakarta), and Sambang Panji (based in Mojokerto, East Java). ${ }^{32}$ Another specific example of application of the Panji values are the activities conducted by artist Agus Bimo Prayitno from Klaten, Central Java: he developed a transformation of a traditional Panji tale into an own creation of puppet show and shadow play, enacting

\footnotetext{
${ }^{32}$ See on facebook.wayang beber kota, wayang beber metropolitan, wayang sakbendino, sambang panji
} 
the values of simplicity (Fig. 15). The participatory programmes stimulate villagers to develop their own creativity and self-esteem. ${ }^{33}$

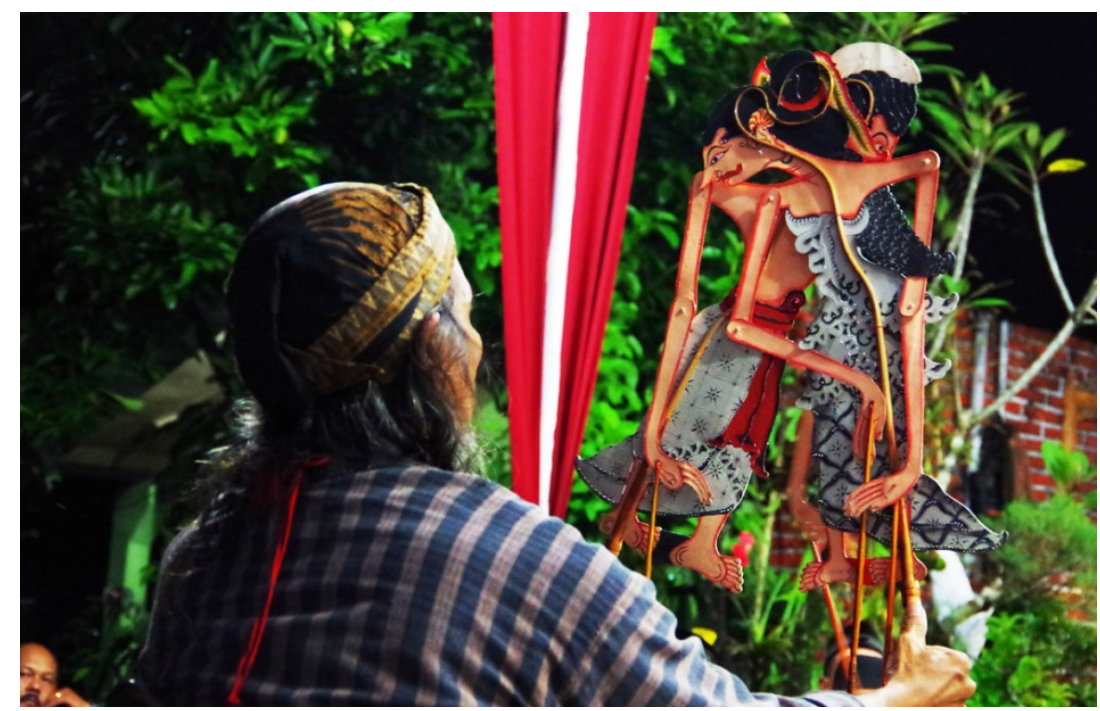

Fig. 15 Performance of Wayang Panji Jantur Udan, self-created puppets of Panji and Sekartaji (image by author)

\section{Conclusion}

The Panji stories were popular during the ancient East Javanese Majapahit period (circa 1300-1500); their roots may go back to earlier times of the Kediri (12 $2^{\text {th }}$ century) or Singasari ( $13^{\text {th }}$ century) kingdoms. The popularity is attested by visual presentations of the stories in the Majapahit State temple Candi Panataran and in other temples. The Panji stories and their presentations have to be seen against the creativity in Majapahit culture, independent of the Indian influence which had dominated the earlier Central Javanese period. Panji is one significant element of this creativity. The Panji theme and tradition later spread over large parts of Southeast Asia.

The revitalization of the Panji theme in Java has great potential of safeguarding this rich cultural heritage in Java; in the same way the revitalization of the Inao tradition will contribute to an increased awareness of cultural heritage in other parts of Southeast Asia. Cultural identity within the whole region, in particular within a time of globalization and radical influences, will be supported through the enactment of this unique tradition in forms of art, performance, literature, and in creations of new forms, transforming the creativity embedded in the Panji theme.

There is still a broad field for research to answer questions such as the following:

- The main question of this paper - getting closer to the primordial Panji? - cannot fully be answered at this stage of research and knowledge.

- In case the Panji tradition spread in Southeast Asia in fact during the Majapahit time, did this spread happen deliberately in order to strengthen the implantation of

\footnotetext{
${ }^{33}$ Started in 2013, with a rapid increase since early 2016.
} 
Majapahit's policy and power? Or did it happen in a "natural" way of diffusion of cultural elements?

- Why were not other stories, significant and popular to Majapahit literature, being transported to other parts of Southeast Asia, such as the Old Javanese kakawin Sutasoma or Arjunawiwaha?

\section{Appendix}

A selection of events and activities in Java during recent years:

2004: First meeting of "Panji enthusiasts" in Surabaya, initiated by Suryo Wardhoyo Prawiroatmojo, co-initiated by Suprapto Suryodarmo from Solo and Lydia Kieven

2007: Festival and Seminar Panji at Universitas Merdeka Malang, Wayang Beber workshop for children in Trawas, choreographies of Panji dance at PPLH (the Centre of Environmental Education) in Trawas

2008: Panji programme at PPLH in Trawas, in cooperation, amongst others, with choreographer Suprapto Suryodarmo and journalist Henri Nurcahyo

2010: Seminar in Candi Panataran; in combination with a workshop for children in painting architecture or specific motives in the temple complex, initiated by journalist Henri Nurcahyo

2010: Workshops for schoolchildren at the Majapahit Museum in Trowulan, thematizing local knowledge and wisdom, including the Panji theme, conducted by Suro Prawiroatmojo

2013: Panji Festival, displaying a competition for school-classes in creations of choreographies on a Panji theme, conducted by the art's association of Blitar (initiated by Wima Brahmantyo and Kholam Shiharta)

2014: Second Panji Festival in Blitar, along with a seminar on Panji

2014: First meeting of Panji enthusiasts ("Pencinta Panji") in East Java, with the intention to interconnect groups, individuals and activities in the field of Panji, with a focus on strengthening and deepening the potential of the Panji theme; establishing a website for publications and a digital museum on Panji

2014: Introduction of the curriculum of Panji Studies at the Department of Tourism at University Ciptura, Surabaya

2014: The National Library in Jakarta held a seminar on Panji in October 2014, going along with an exhibition of Panji manuscripts from the library. This programme makes part of the application process of including the collection of the Panji stories manuscripts as property in the list of UNESCO Memory of the World

2015: "Tour Panji": Visit of temples and sites in the region of Blitar having Panji reliefs, initiated by Yayasan Pring Woeloeng, conducted by Lydia Kieven

2015: City and District of Kediri conduct events of performances and rituals having the Panji theme, titled "Panji pulang kampung", "Panji bersih desa".

2016: Nomination of the Panji stories manuscripts of the National Library to be established as Memory of the World (final decision expected in October 2017)

2016: Performances of "Wayang Panji Jantur Udan" in the region of Klaten and Yogyakarta, initiated by Agus Bimo Prayitno 
2017: Opening of the Panji Museum in Malang (planned mid-2017), East Java (founded by Dwi Cahyono)

2017: Festival Panji Nusantara in Kediri, conducted by the Department of Tourism and Culture of the Province of East Java, by the city and district Kediri, by the National Library (July 2017)

2017: Panel on "Panji and cultural patterns in Southeast Asia" at the conference of EUROSEAS in Oxford, England, in August.

Planned for 2018: International Festival in Kediri and Jakarta (same operators as the festival 2017)

Since 2014: increasing number of Panji seminars and mask dance performances in East and Central Java.

A few websites and Facebook groups have been established throughout the last years. $^{34}$

\section{Bibliography}

Agus Aris Munandar and Ninie Susanti (2014) Makna Kisah Panji. In: Perpustakaan Nasional Republik Indonesia (ed) Prosiding. Seminar Naskah Kuna Nusantara "Cerita Panji Sebagai Warisan Dunia”, Jakarta, 28-29 October 2014, 5-19.

Berg, CC (1954) Bijdragen tot de kennis der Panji-verhalen. BKI 110: 189-216, $305-$ 334.

Creese, H (2004) Women of the Kakawin World: Marriage and Sexuality in the Indic Courts of Java and Bali. Armonk, New York: Sharpe.

Cribb, J (1999) Magic Coins of Java, Bali and the Malay Peninsula: Thirteenth to Twentieth Centuries. A Catalogue Based on the Raffles Collection of Coinshaped Charms from Java in the British Museum. London: British Museum Press.

Davisakd, P (2007) The Pursuit of Java: Thai Panji Stories, Melayu Lingua Franca and the Question of Translation. PhD Thesis, National University of Singapore, Singapore.

Feillard, A (2010) The End of Innocence? Indonesian Islam and the Temptation of Radicalism. Honolulu: University of Hawai'i Press.

Forge, A (1978) Balinese Traditional Paintings. Sydney: Australian Museum.

Hitchcock, M, King, V, and Parnwell, M (2010) Heritage Tourism in Southeast Asia. Copenhagen: Nias.

Hughes-Freeland, F (2008) Embodied Communities: Dance Tradition and Changes in Java. New York: Berghan.

Kieven, L (2013) Following the Cap-Figure in Majapahit Temple Reliefs: A New Look at the Religious Function of East Javanese Temples, $14^{\text {th }}$ and $15^{\text {th }}$ Centuries. Leiden: Brill.

\footnotetext{
${ }^{34}$ ppanji.org, http://budayapanji.com/informasi, https://waybemetro.wordpress.com/ Facebooks groups: Pencinta Panji, Sahabat Panji dan Sekartaji, Wayang Beber Kota, Panji Sakbendino, and others.
} 
Kieven, L (2014a) Menelusuri Figur Bertopi dalam Relief Candi Zaman Majapahit: Pandangan Baru terhadap Fungsi Religius Candi-Candi Periode Jawa Timur Abad ke-14 dan ke-15. Jakarta: EFEO / Kepustakaan Populer Gramedia.

Kieven, L (2014b) Simbolisme Cerita Panji dalam Relief-Relief di Candi Zaman Majapahit dan Nilainya pada Masa Kini. In: Perpustakaan Nasional Republik Indonesia (ed) Prosiding Seminar Naskah Kuna Nusantara "Cerita Panji Sebagai Warisan Dunia”, Jakarta, 28-29 October 2014, 263-280.

Kieven, L. (2016) Panji and Candrakirana lost in separation. Amerta 34 (1), June 2016: 31-48. Jakarta: Pusat Penelitian Arkeologi Nasional.

Mulder, N (1998) Mysticism in Java: Ideology in Indonesia. Amsterdam: Pepin Press.

Henri, N (ed.) (2009) Konservasi Budaya Panji. Surabaya: Dewan Kesenian Jawa Timur.

Perpustakaan Nasional Republik Indonesia (ed.) (2014) Prosiding Seminar Naskah Kuna Nusantara “Cerita Panji Sebagai Warisan Dunia”, Jakarta, 28-29 October 2014. Jakarta.

Poerbatjaraka, R.M.Ng (1940) Pandji-verhalen onderling vergeleken. Bandoeng: Nix \& Co. [Bibliotheca Javanica 9.]

Poerbatjaraka, R.M.Ng (1968) Tjerita Pandji dalam perbandingan. Jakarta: Gunung Agung.

Pott, PH (1966) Yoga and Yantra: Their Interrelation and Their Significance for Indian Archaeology. The Hague: Nijhoff.

Rassers, WH (1922) De Pandji-roman. Antwerpen: De Vos-Van Kleef.

Ricklefs, MC (2006) Mystic Synthesis in Java. Norwalk: East Bridge.

Robson, SO (1971) Wangbang Wideya: A Javanese Panji Romance. The Hague: Nijhoff.

Robson, SO (1999) The Cave Scene or Bussaba Consults the Candle. BKI 155: 57995.

Romondt, VR van (1951) Peninggalan-peninggalan purbakala di Gunung Penanggungan. Jakarta: Dinas Purbakala Republik Indonesia.

Smith, L (ed.) (2009) Intangible Heritage. London: Routledge.

Stutterheim, WF (1935) Enkele Interessante Reliefs van Oost-Java. Djawa 15: 13044.

Stutterheim, WF (1936a) Voorloopig bericht omtrent enkele vondsten op den Penanggoengan in 1935. Djawa 16: 194-200.

Stutterheim, WF (1936b) Een Pandji-kop uit de 15e eeuw. Maandblad voor Beeldende Kunsten jg. 13: 329-35.

Suleiman Satyawati (1978) The Pendopo Terrace of Panataran. Jakarta: Proyek Pelita Pembinaan Kepurbakalaan dan Peninggalan Nasional.

Van Romondt, VR (1951) Peninggalan-peninggalan Purbakala di Gunung Penanggungan. Jakarta: Dinas Purbakala Republik Indonesia.

Vickers, A (2005) Journeys of Desire: A study of the Balinese Text Malat. Leiden: KITLV Press.

Vickers, A (2015) Majapahit and Panji Stories. In: Catrini Kubontubuh and Peter Carey (eds), Majapahit - Inspiration for the World. Jakarta: Arsari, 47-64.

Zoetmulder, PJ (1974) Kalangwan: A survey of Old Javanese Literature. The Hague: Nijhoff. 